dence. Disposed to the waggish himself he attempts to trick the reader by coyly misattributed quotations; his favourite word is "whimsical"; he often refers delightedly to Frank L. Baum's Oz stories - he would clearly welcome a deity whose disposition is similar. Perhaps, he hopefully suggests, the universe is "a vast cosmic jest fabricated by a god who had no motive except to amuse himself and his friends". This cosy concept is discouraged, though, by memories from Gardner's fundamentalist education: God only laughs four times in the Bible; on each occasion, he is chortling over the fate of the damned.

Moving from the Old Testament to the new physics, jumbling quarks and quirks, Gardner's book is a weird blend of sophisticated cerebration and psychological naivety. In approach, it can be callow, full of sleeve-tuggings and leg-pullings. Being button-holed - "But wait! . . Perhaps, dear reader ..." - is a recurrent experience. Ratiocination roguishly collapses into an exaggerated throwing up of hands: "Is it true? Don't ask me. How could I possibly know? I put it forth whimsically". As much a wise guy as a "whys" man, Gardner can be alienatingly facetious - yet this doesn't stop his book from often being genuinely funny. Reverent gazings at the after-life co-exist with a sharp eye for the here and now. Political fatuities are savoured. And Gardner likes to pounce sardonically on Christian crassnesses - from the contemporary childishness of the born-again, carolling out that "Matthew 24 is Knocking at the Door" to medieval implements for uterine baptism of embryos. Oddly, a book introduced as simply "about what I believe and why" is at its keenest when debunking the bizarre beliefs of others.

Peter Kemp is Senior Lecturer in English at the MiddlesexPolytechnic, London. He is author of H.G. Wells and the Culminating Ape (Macmillan, 1982).

Who got where when

Nicholas Wade

Exploring the Earth and the Cosmos.

By Isaac Asimov.

Crown/Allen Lane: 1982.

Pp.352. \$13.95, £8.95.

ACCORDING to the dustflap of this book, Isaac Asimov's two-hundredth book was published in 1979. The present work is doubtless his 210 th, a fact that must make any reviewer lay aside, at least for a few seconds, the pose of omniscient scorn his kind is obliged to affect. A writer who has published 200 popular books is certainly a master of his craft, like it or not.

Exploring the Earth and the Cosmos is a craftsmanlike compendium of the history of geographical and extraterrestrial exploration. It is taut with pertinent facts, lucidly and deftly presented. It tells you the temperature of the planet Mercury, the distance to Alpha Centauri, the height of many great mountains and the depths of many profound abysses. It relates, with Guinness Book of Records exactitude, who got where first.

In this connection, Asimov may perhaps be a little too clement to the claims explorers make. He cites Admiral Peary as the first man to reach the North Pole, and since Encyclopaedia Britannica does likewise, he shall not be faulted for that. The astronomer Dennis Rawlins, however, showed in a book of 1973 that there is strong reason to doubt the good Admiral ever went near the pole. Since explorers tend to have few independent witnesses, but patrons and a public to satisfy, their claims often merit some scepticism.

It is here perhaps that Mr Asimov's relentless march of facts begins to provoke a twinge of fatigue in the reader. At some point people become more interesting than things to even the most hardened misanthrope. Someone had to be first to the North Pole; who cares if it was Admiral Peary or Eeyore? But if Admiral Peary was spinning a yarn, that's a story that can be sat up for. Similarly the Venetian master Titian is earnestly cited for his longevity, but Titian was not the first to let his anticipation of a pension outweigh his appetite for factual exactitude. Modern scholars believe he was born in 1488, not 1477 as Titian and Asimov declare.

Expansion of physical horizons is the theme that threads the book together. $\mathrm{Mr}$ Asimov concludes by noting that "there are other horizons that have expanded magnetic intensity, viscosity, angular momentum, etc - but those I have present are sufficient to show humanity at its most magnficently human ..." The observation evokes the image of someone swimming through molasses in a 5 tesla field at $33 \mathrm{~g}$, which would surely be as fine a testament as any to the human side of humanity. The weakness of the book is that Mr Asimov's interest in facts is inexhaustible, his attention to motive exiguous. Yet without motive, who would ever leave home to go exploring either Earth or cosmos?

Inclusion of the details that interest historians, however, would have extended the book beyond any reasonable scope. $\mathrm{Mr}$ Asimov's aim was to distill the quintessence of fact, and he has succeeded excellently. Yet the book is probably one that more people will find useful as a work of reference than will read for pleasure.

Nicholas Wade is an editorial writer on the New York Times and co-author of Betrayers of the Truth (Century, 1983), an analysis of fraud in science.

\section{Smoothing the flow of data}

\author{
T.A. Kletz
}

How to Write and Publish a Scientific

Paper, 2nd edn.

By Robert A. Day.

ISI Press: 1983. Pp.180. Hbk \$17.95; pbk \$11.95.

MANY who have to read scientific papers, reports and memoranda, published and unpublished, will have sympathized with the chairman of a recent Inquiry, who wrote in his report, of the written evidence he had received, "Turgid and indigestible as some of it was, the Assessor and I read it, though often with little profit". Many scientific and technical reports are badly written. (Is this why so few technologists seem to read books for pleasure? Does the garbage they have to read put them off all reading?) I therefore turned hopefully to the new edition of Day's book. Could I recommend it to colleagues, past and present? It is well-written, it was a pleasure to read (I must get my tenses right), it contains many amusing anecdotes, but a better title would be 'All you need to know about writing a scientific paper except what words to use' or 'How to make life easier for editors'

This book covers choice of title, the abstract, the manuscript, the diagrams, layout of tables, references, proofchecking, ordering reprints and other such matters but only two short chapters deal with the actual choice of words. The author claims that if you organize the paper properly it will write itself, but this is not so. You could follow all his advice (except for the two chapters I have mentioned) and produce an unreadable paper; you could ignore all his advice and produce a paper that is a pleasure to read and which influences its readers, even though the tables take up more room than they need and the references are a mess. In fact, Day like many editors, almost forgets that it is the content that makes a paper and not the layout.

There is no reason why authors should not follow his advice and make his life easier - it is sloppy to have references arranged inconsistently, for example but readers are (we hope) more numerous than editors and it is therefore more important to make their life easier by developing a clear style, particularly if you are writing for a wider public. Fellow workers in your field may persevere; others will not.

Day paints a picture of the editor as a man martyred by authors who will not follow his advice. As an author I do not quite see it that way; it is me (or my papers) that are afflicted. I could quote many examples of editors who have changed what they did not understand, shortened 
articles so that they are finished at the bottom of a page and removed humorous examples that they considered too frivolous. I think of editors as dour, darksuited Presbyterians, unwilling to let any humour into the serious business of imparting knowledge. I, on the other hand, agree with W. S. Gilbert that "he who'd make his fellow creatures wise, should always gild the philosophic pill", but my quotations from Lewis Carroll, my mathematical treatment of belt and braces to show how the reliability of two protective systems is calculated, have often been blue-pencilled.

Editors favour brevity; it is cheaper. But repeating a statement in different words often helps to get the point across. If the author of psalm 114 had been writing for a geological journal he would not have got away with "The mountains skipped like rams, and the little hills like lambs".

In emphasizing form rather than language Day almost treats scientific papers as art rather than a means of communication. Perhaps he is right to do so. Information scientists tell us that many papers are never read by anyone (except writer, editor and referee) and that at least $25 \%$ are never cited, even by the author. Just as medieval sculptors took great pains over the carving of cathedral roofbosses, that no one would ever see, so editors take great pains over the presentation of papers that no one will ever read. Depending on your point of view, both are a waste of time or art for art's sake: pride in a job done well, whether or not it is ever seen.

In a hard, commercial world is it really cost-effective to spend so much effort perfecting a paper to Day's satisfaction? Recently I spent many hours looking up the references to a longish review paper because the editor wanted more details than usual. It is sloppy, I agree, not to follow a journal's style, but how far do you go when life is limited? Do we aim for a perfect job or an adequate job?

The coming years may make much of what Day wants out-of-date. Already some publishers, as he points out, are setting type directly from the author's word-processor discs. This makes it harder for them to edit the text. The next step will be to cut out the typesetting altogether and feed the author's disc into a computer data base which readers can access, taking a hard copy if they want. Farewell, Mr Day.

In the meantime, his book should be widely available wherever scientific papers are written and all authors, particularly first-time ones, should be encouraged to read it. It will not solve all their problems; it will not solve their biggest problem, learning to write well, but it will smooth the path to publication and that is worth doing. Day has set himself a modest task and done it superbly.

T.A. Kletz has retired from the chemical industry, and is now a professor in the Department of Chemical Engineering at Loughborough University.

\section{Usage and abusage}

\section{Walter Gratzer}

Fowler's Modern English Usage, 2nd edn.

Revised by Sir Ernest Gowers, 1965.

Oxford University Press: 1983.

Pbk with corrections. Pp. 725.

£3.25, \$8.95.

THE redoubtable Dr Burchfield is said to be embarking on a new edition of Fowler. Meanwhile Gowers' revision, available for the first time in sturdy paperback and a snip at the price, will do very well; no laboratory should be without it, if for no better reason than that a ramble through the scientific literature with Fowler as guide affords no end of macabre entertainment.

There is, as I understand, one scientific paper published every second. If Balzac could describe Georges Sand as a great cow full of ink, what are we to say about some of our capi mafiosi, who-I judge by some recent obituaries - are capable of putting out two thousand papers in a working life? (Who would have thought the old man had so much ink in him?). We live in a slop of overflowing neologisms, pleonasms, malapropisms, clichés and unattached participles.

Scientists, even more than journalists, batten onto each new distortion of language with an uncritical eagerness that they would never think to apply to the substance of their papers. Examples of current vogue words that come quickly to mind are 'probe', to mean any vehicle of observation, 'propose' to mean suggest, as in 'we propose that the core of the earth consists of molten Camembert', and 'abolish' to mean expunge, not a law or statute, but something on the lines of enzymic activity.

Even more striking is the way in which words with a precise technical meaning escape into the outside world, are mangled by journalists and politicians, and are then received back in their new and perverted sense. 'Parameter' for example is now widely used in the scientific literature, as in newspapers, to mean any measured quantity or constant (or, for that matter, variable), and 'extrapolate' and 'exponential' appear to be undergoing a similar malignant transformation. And how has 'multimer' suddenly surfaced, to signify apparently something that is smaller (or perhaps bigger) than an oligomer? (The proponents of this idiotic usage might not be aware of the old don's comment on television, when that medium began to assert itself: no good, he said, would come of an invention, the name of which was half in Latin and half in Greek).

Fowler is excellent on vogue words and admirably cool and dispassionate about such emotional issues as split infinitives and terminal prepositions. He concludes his dissertation on the latter with the comment that not even Dryden, who denounced the practice, would have changed "which I will not put up with" to "up with which I will not put". (As a counter-example I would offer the child's question: 'what have you brought me that book to be read to out of for?').

Fowler is splendid on ambiguities. Here are two of his illustrations (presumably genuine) from the several categories that he considers: "to ask the Minister of Agriculture if he will require eggs to be stamped with the date on which they were laid by the farmer", and "Miss Pickhill grasped the pince-nez, which hung from a sort of button on her spare bosom". My own choices in this genre would be the exhortation on London Transport escalators that "dogs must be carried" (why should such an encumbrance be thought necessary?), the notice at one time displayed in the windows of a chain of chemists' shops, proclaiming "we dispense with accuracy", and the legend on the sides of removal vans, which used to be seen plying about London: "Removers of Distinction" it proudly asserted.

Fowler is a marvel of easy erudition and yields much diversion and instruction. I recommend it for browsing, for improving one's papers and resolving arguments and for confounding subeditors. I hope it finds its way across the Atlantic, whence the following, as an example of scientific prose to make your knees buckle: "Remarks as to the handiness of germane magnetic facts strongly parallel those made in antecedent paragraphs concerned with spectroscopic conduct. Generally speaking, magnetic demeanor is more greatly influenced by environmental vagaries than optical deportment, as the former is dependent upon the detailed visitatorial schedules of the transient electrons." Perhaps the computers are taking over. As that legendary master of the modern malapropism, Sam Goldwyn, nearly said, if Fowler were alive he'd be turning in his grave.

Walter Gratzer is in the Medical Research Council Cell Biophysics Unit, King's College, London.

\section{Gripes or wrath?}

Our reviewer has given some examples of uncouth English usage, commonly found in the scientific literature. We propose to consider correspondence, in which readers can (briefly) air their prejudices, reflections and hates on scientific prose, its content, style and vocabulary. Contributions to our correspondence column on these matters are invited. 